to go whaling when the stocks increase. But if this is a dream, then the alternative, the present lack of any effective conservation, is a nightmare. We are running rapidly towards the possible extinction of the whale, and to the certain extinction of the whaling industry, and the food it supplies to the world.

\title{
THE NEW WHALING AGREEMENTS
}

$\mathbf{M}^{\mathrm{o}}$ ORE jam for the whalers this year, and a promise to be less greedy next year and the year after, are the main results of the two meetings of the International Whaling Commission in London this year. The outcome for the whales cannot be said to be hopeful, at any rate for those who take a realistic view of international promises to do better in future. Last season the catches were more than twice the amount the stocks could stand - though they were less than the whaling countries expected to get-and were only maintained by the whalers concentrating on the sei whale (a smaller relative of the blue and fin whales). Before 1963 sei whales were not of much interest to the whalers, but in the $1964 / 5$ season some 20,000 were killed-about one-third of the total Antarctic stock.

Faced with a recommendation from their scientific advisers that, in order to prevent the further depletion of stocks, not more than 2,500 blue whale units should be taken in 1965/66 (one b.w.u. equals two fin whales or six sei whales), the IWC at its May meeting could do no better than agree on a compromise proposal of nearly double this figure, 4,500 , with a promise to accept realistic quotas in $1966 / 67$ and $1967 / 68$ that would ensure the rebuilding of world stocks. As has happened before, most countries agreed to an unrealistic figure in order to preserve the pretence of adherence to an international agreement. This decision was confirmed at the second London meeting in June, which also decided to look into the questions of incorporating the catches of the land stations into the quota system, and the conservation of whale stocks in the North Pacific.

The FPS was represented by observers at both meetings of the IWC, and had urged the adoption of three measures: the adoption of realistic quotas to allow the vastly depleted stocks to build up again; the incorporation of the land stations' catches in the quota system; and separate quotas for individual whale species instead of the overall blue whale unit. The first two of these may or may not be achieved next year.

On the credit side can be placed the agreement to prohibit the taking of blue and humpback whales in the North Pacific, though against this it has to be remembered that any country may object to these proposals within 90 days of the meeting. This is what happened over the total protection of the blue whale in the Antarctic proposed at the last meeting: all the pelagic whaling countries objected. The result is that blue whales are still not protected in Antaretic waters north of $55^{\circ}$ between $0^{\circ}$ and $80^{\circ}$ East. Informed world opinion will condemn Norway, Japan and Russia for this extraordinary piece of short-sightedness.

One reason for the Japanese insistence on an unrealistically large quota in $1965 / 66$ is the failure of the Russians to agree on the international observer scheme, designed to check that all whaling ships observe the quotas. The reason for the Russian attitude is probably to be found in the doubts about the reliability of many of the whale statistics, the majority of which, as the "New Scientist" has pointed out, appear to be doctored in one way or another. The other main Japanese motive is the need to recoup on the large capital expenditure on their whaling fleet. Once more short term considerations of finance have been allowed to risk the long-term destruction of a natural resource. 